\title{
Research
}

\section{The Dynamics of Social Capital and Conflict Management in Multiple Resource Regimes: A Case of the Southwestern Highlands of Uganda}

\author{
$\underline{\text { Pascal C. Sanginga }}^{1}$, Rick N. Kamugisha $^{2}$, and Andrienne M. Martin ${ }^{3}$
}

\begin{abstract}
Increasingly, social capital, defined as shared norms, trust, and the horizontal and vertical social networks that facilitate coordination and cooperation for mutually beneficial collective action, is seen as an important asset upon which people rely to manage natural resources and resolve conflicts. This paper uses empirical data from households and community surveys and case studies, to examine the role, strengths, and limits of social capital in managing conflicts over the use and management of natural resources. We inventoried over 700 cases ranging from conflicts between multiple resource users to supracommunity conflicts between local communities concerns for better livelihoods and national/international concerns for environment conservation. Results show how different types of social capital are used in preventing and managing conflicts. Endowment in certain dimensions of social capital significantly decreased the occurrence of conflicts and played a significant role in managing them. However, social capital mechanisms have some limits, and are not always effective in resolving some types of conflicts. For such conflicts, people rely on formal mechanisms for arbitration and adjudication. In many cases, these have resulted in exclusion, coercion, and violence. Results show that policies or social capital alone do not possess the resources needed to promote broad-based and sustainable conflict resolution strategies. Rather, people use a range of conflict management strategies of different types and combinations of social capital and local polices. This synergy between social capital and local policy is based on complementarity and embededness: mutually supportive relations between local government and local communities, and the nature and extent of the ties connecting people and communities and public institutions. Better understanding of how this synergy between social capital and local policy can be strengthened is crucial to minimize natural resource management conflicts.
\end{abstract}

Key Words: bylaws; conflicts; gender; highlands; natural resources management; social capital; synergy; Uganda.

\section{INTRODUCTION}

The policy environment for natural resource management (NRM) is changing dramatically from centralized top-down conservation approaches, to community-based livelihood approaches, which are increasingly seen as offering pro-poor alternative to resources management (Borrini-Feyerabend 1996, Agrawal and Gibson 1999, Knox et al. 2002, Meinzen-Dick et al. 2002, Russel and Harshbarger 2003). In Uganda, recent decentralization efforts have reinforced pluralism in property regimes with porous boundaries both of regimes, stakeholders, and uses, and complex relationships among a wide range of social actors and resource users. The intensively cultivated and densely populated southwestern highlands of Uganda are characterized by fragile agroecology, with a combination of uses, users, resources, and rules that govern resource use. In this context, NRM can be typically described as a "commons" (Ostrom 1990) with overlapping combinations of porous boundaries both of regimes and stakeholders, and when actions by individuals or groups often generate off-site effects. In such fragile environments, people compete for the natural resources they need to ensure or enhance their livelihoods. NRM is in many ways a form of conflict management (Hendrickson 1997, Buckles and Rusnak 1999, Castro and Nielsen 2003).

These conflicts are intensifying and if continued to be ignored, they can escalate and result into further 
degradation of natural resources, erosion of social and human capital, and pose significant challenges to sustainable rural livelihoods (Hendrickson 1997, Scott 1998, Buckles 1999, Means et al. 2002, Castro and Nielsen 2003). Therefore, the management of the inevitable conflicts in NRM is important as public good, and merit policy support (Tyler 1999). Any policy support must rely on a detailed and systematic understanding of the nature, types, dimensions, and implications of conflicts and their management mechanisms. Much of the literature on conflict management emphasizes social institutions as mediating factors that govern the relationship between a society or community and the natural resources on which it depends, and therefore emphasizes the relationship between social and natural capital (Rasmussen et al. 1995, Orostom 1998, Upreti 1999).

Most of this research has shown the importance of social capital foundations for sustainable management of natural resources, successful policy interventions, and community development (Uphoff and Mijayaratna 2000, Woolcock and Narayan 2000, Pretty 2003, Bridger and Luloff 2001, Grant 2001, Grootaert 2001). Its reinforcement and continued deployment in a society is what maintains both the existence of particular institutions and the process of institutional innovations within the society. The emphasis on social capital is based on the assumption that communities are more efficient than state structures in the management of commonpool resource conflicts. However, although literature on social capital has emerged in the last decades, there is still limited empirical information on the role of the different dimensions of social capital in managing conflicts. The central hypothesis of this paper is that presence of social capital is a necessary precondition for the management of NRM conflicts, and for sustainable management and use of common pool resources at the local level. This paper examines the different types of conflicts over the use and management of natural resources, and determines the role, strengths, and limits of social capital in managing NRM conflicts. The rest of this paper starts with the description of status of natural resources in Kabale and their different property regimes. Then, we examine the prevalence and the different types of conflicts over the use and management of natural resources. The sections that follow examine the role, strengths, and limits of social capital mechanisms for managing conflicts. The concluding section suggests a framework for strengthening synergy between social capital and policy, and building local capacity for alternative conflict management.

\section{NATURAL RESOURCES MANAGEMENT REGIMES IN THE HIGHLANDS OF KABALE, UGANDA}

The study was conducted in Kabale district in the southwestern highlands of Uganda. Kabale district has an estimated population of 461,785. Population density exceeds 350 inhabitants $/ \mathrm{km}^{2}$ in several areas, making Kabale one of the highest densely populated rural districts in Uganda. Population pressure has continued to increase resulting in fragmented small farms, i.e., $0.25-1.0$ ha for an average family of six, and steep cultivated slopes (1500-2700 masl). Several scholars have extensively documented the status of natural resources management (NRM) and technologies for reversing land degradation in the highlands of Kabale. For a summary of studies see Tukahirwa (1997), and Raussen et al. (2002) for inventory of technologies. The status of agricultural-based NRM in the highlands of Kabale cannot be better summarized than with this explanation by an elderly farmer, Zaburooni, now in his late 70s, who came to the village in 1944 when he was about 18 years old:

This area was not occupied before the 1940s. The first people settled on the hilltop, as there were forests and jungles lower down. There were about seven families present at that time. They built houses on the top and cultivated around the houses. ...When more people came to the area, the clan leaders would allocate enough land that could support a family, depending on the family size. They did not think about the future or acquire huge chunks of land ready for expansion. ...In the past you could stand on a hilltop and only see another hilltop because of the dense and tall bushes in the valley. Everything was just trees; all the valleys and slopes were also covered with forest. (...) Cultivation started at the mid slopes, moving down to the lower slopes, in order to scare away predators (wild pigs, leopards and lions). (...). The east-facing slope was the first to be cultivated, starting from the mid slope to the valley, then expanding south on the 
eastern slope. (...) We used to plant plots in alternate years (3 to $5 \mathrm{yr}$, even more) to regain its fertility. When you leave a plot to rest, grasses grow up and later rot and the soil gains its fertility (...). The hills top and valley bottoms were used as grazing lands for everybody. Now because many people came into the village and with constant tilling without resting the land, people are now forced to cultivate both the valley bottoms and the hilltops. Some rich and powerful people have also bought the fertile parts of the valley bottoms for their exotic dairy cows. Some used their power to grab communal grazing land, like the whole of that hill...The Government also is stopping people from using the wetlands and swamps, where we used to fish and collect papyrus and building material. Now people are arrested for collecting papyrus from the swamps, or firewood from a village woodlot...This is very difficult for the poor and old people like me who don't have money. When we came to this village, money was not the issue, and there were plenty of resources for the village. Now we have so many disputes over the use and property of land, even for grazing land and other communal properties. People are now competing for everything (...)

Historically, NRM regimes were often regulated through customary and traditional institutions and dispute resolution mechanisms. These institutions still operate through clans and other farmers local associations. Clans play an important role as an important feature of social organization that facilitates coordination, cooperation, and for managing the social structures and institutions for NRM (Place et al. 2001). Though local communities have long been known to manage their NRM effectively over a long period, many common- pool resources have now come under the jurisdiction of the state, turning some into protected areas, and restricting the use of many others with strict policies. Even in the case of private property regimes, individual farmers are not entirely free to decide for themselves how to make use of natural resources, but participate in a process of collective choice that sets rules and regulations, or bylaws for individual and collective use.
The penetration of the State was accompanied by the breakdown of traditional practices and the emergence of strict regulations or policies based on the traditional conception that common-pool resources (CPR) need protection from the destructive actions of people and local communities. The authority for resource use has been invested in government institutions by the colonial legacy. Most of the initial laws in Uganda, as in most parts of Africa, were not drafted in the interests of the communities that lived near these resources. After the independence in 1962, government policies have concentrated on their conservation mandate for the protected areas, paying little attention to the legitimacy of the needs and rights of local communities, but implementing policies imposed by international conservation treaties and conventions.

For decades there has been systematic failure to recognize that traditional institutions and local knowledge has been the basis of the survival of most rural communities. However, over the last decade, the decentralization of government and environmental management, various government policies, and institutions recognize the right of communities to participate in environmental management, and recognize that local communities can manage common pool resources in an effective and sustainable manner. The mechanisms of decentralization are established and functioning, with the structure of a five-tier system of local councils and local government structures (Table 1), a bottom-up planning process, and powers to collect and disburse local revenue, develop and implement bylaws and local policies for land use, environmental management, and agricultural production (Sanginga et al. 2004). At the base of the local government structure, the local council or LC1, A village of about 50-100 households, consists of all adults residing in a particular village who elect a ninemember village local council executive committee. Beyond the village or LC1, in ascending geographical size, there are parishes (LC2), subcounty or gombolola (LC3), county (LC4), and district (LC5) councils. The subcounty level (LC3) is the basic unit of local government, both political and administrative. The district (LC5) is the highest level of local government and links with central government. The provision of local government elections guarantee widespread representation at the various councils and include quotas by gender, people with disabilities, and youths. For example, 
at least one-third of the council members must be women, an affirmative action to empower women and promote gender equity.

In this paper, we use the term policy in its broad sense to refer to laws, rules, and regulations and their implementation resulting from public, state, or collective decision making (Thomson 2001, Means et al. 2002). Policies can be generated and operate at different levels: international, national, regional, district, and local levels. In this study, we are particularly concerned with those local-level policies and community regulations usually referred to as bylaws. Bylaws are rules made by lower local government councils (LC1 and LC3) and provide the local policy guidelines to be followed in sectoral developments, such as agriculture and natural resource management. These bylaws or local arrangements for natural resource management are now receiving greater attention as a viable alternative for enforcing government policies and rectifying their inefficiencies in agriculture and NRM (Sanginga et al. 2004).

In a social capital framework, these local policies or bylaws can be defined as negotiated rules, social norms, and agreed behaviors that exist within communities to prevent and manage conflicts. Colleman (1988) identified different forms of social capital: obligations and expectations, informal channels, and social norms. Fukuyama (1999) and Bowles and Gintis (2002) regard social capital as an instantiated set of informal values or norms shared among members of a group that permits to cooperate with one another. It is the willingness to live by the norms of one's community and to punish those who do not. In the context of this study, bylaws are rules made by lower local decentralized councils and local communities and provide viable alternative for enforcing government policies and rectifying their inefficiencies in agriculture and NRM.

\section{TYPES AND DIMENSIONS OF CONFLICTS OVER THE USE AND MANAGEMENT OF COMMON-POOL RESOURCES}

We define conflicts as situations involving people or social groups with different interests, and mutually antagonist tendencies and opposing influences competing for the use of limited resources to ensure or enhance their livelihoods (Mitchell 1981 in ACTS 1999, Means et al. 2002).
Their manifestations, dimensions, and level of intensity vary greatly. They can be implicit or explicit, proximate, local, regional, national, or international, latent or violent. Following Ramirez (1999) and Means et al. (2002), the analysis of conflicts began with identifying and describing the conflict, its boundaries and interrelationships, the origins, levels, issues, and stakeholders. To encourage people to speak about and see conflicts as part of human interactions, we asked:

"From working in other areas, we have seen that problems and disputes over the use of natural resources, e.g., land, crops, trees, livestock, wetlands, forests, can be common among people in the same area. Would you give use some examples of such problems and disputes in your areas? Please tell us what was the problem, who was involved? What were the reasons? How have the people tried to address the conflict? How were problems resolved? What was accomplished? What were the consequences or damages caused?"

We interviewed 203 farmers in 16 villages and found that almost all the farmers have been involved in conflict over the use and management of natural resources in one way or another. About $43 \%$ of farmers have experienced at least one to three conflicts, whereas the majority $(55.6 \%)$ has experienced more than three conflicts. One out of each five households has experienced more than seven conflicts (Table 1). There was however no significant difference in the number of conflicts reported by men and women $(t$ value $=-0.327)$. The survey inventoried 701 conflict cases. These conflicts are multifaceted, multidimensional, and multiscale, involving a variety of stakeholders and resource users ranging from intrahousehold and suprahousehold gender relations, property rights disputes to antagonist, distrustful relationships, and violent clashes amongst and between farmers, local communities, government, and external institutions (Table 2).

These conflicts can however be grouped into three broad categories: community-level conflicts opposing farmers within same communities; intercommunity conflicts opposing different communities or farmers from neighboring villages, and supracommunity conflicts opposing farmers and communities with higher-level formal institutions or individuals. The most common type of intracommunity-level conflicts concerned hillside management, causing destruction of terrace 
Table 1. Levels and main functions of decentralised local government structures in Uganda.

\begin{tabular}{l}
\hline Local Government 1 Level \\
\hline Local Council 1: Village \\
(composed of more or less 50 \\
households
\end{tabular}

households

LC 2: Parish (composed of 3-10 villages)

LC 3: Sub-county (Composed of 2-10 parishes)

LC 4: County (composed of 3-5 sub-counties)

Composition Functions

9 members, at least 4 women

Assist in maintaining law, order and security

Initiate, support and participate in self help projects

Recommend persons for local defence units

Serves as communication channels with government services

Monitor the administration of projectsImpose service feesCollect taxes

Resolve problems and disputes Make bylaws

Depending on the number of Assist in maintaining law, order and security villages elected from the village at least 4 women

Serves as communication channels with government services

Initiate, support and participate in self help projects

Monitor the administration of projects

Resolve problems and disputes

Depending on the number of parishes, 1/3 women

2 youth

2 persons with disabilities

Elected councillors from parishes

Local government

Enact bylaws

Approve subcounty budget

Levy, charge, and collect fees and taxes

Monitor performance of government employees

Formulate, approve and execute sub-county budgets

Resolve problems and disputes

5 , chairpersons or vicechairperson from each subcounty
Advise district officers and area members of Parliament

Resolve problems and disputes

Monitor delivery of services 
LC 5: District (composed of 3-5 counties)
36 members
12 women councillors
2 youth
2 people with disabilities
19 elected councillors

Exercise all political and executive powers

Provide services

Ensure implementation of government policies and compliance with it

Plan for the District

Enact district laws and ordinances

Monitor performance of government policies

Levy, charge and collect fees and taxes

Formulate, approve and execute district budgets

Source: Sanginga et al (2004)

bunds and boundary disputes, which affect over $70 \%$ of households. This type of conflict is fuelled by the excessive fragmentation of very small agricultural land, and the high competition over the use of farmland. This increasing competition has also created different types of conflicts related to property rights $(43.9 \%)$, from competing inheritance claims, illegal sale of land, land grabbing, and other issues of resource ownership and access, destruction of terraces, cutting of trees and theft of resources. More than 74\% of households were affected by conflicts arising from animals grazing on field crops. This type of conflict is more pronounced shortly after the planting season when livestock graze on young plants and trees. Most communal grazing lands have been turned into individual properties and farmland, leaving people with livestock with limited resources for grazing their animals. Other forms of conflicts included bush burning (40\%), cutting of trees $(43 \%)$, and theft of crops, livestock, and farm implements $(45 \%)$.

Competing rights and claims often caused intercommunity conflicts over common pool resources, e.g., wetlands, grazing lands, woodlots, and paths, theft of resources, as well as bush burning. Bush burning often started by herd boys or by farmers as a land preparation practice has caused several conflicts within and among communities, especially during the dry season. In many cases, such fires have been difficult to control and have destroyed property, sometimes even burning houses. In some cases, the competing claims over common-pool resources (CPR) have resulted in violent clashes among farmers and among communities as illustrated in this case:

Farmers from these three neighboring villages used to graze their animals communally on one hill and valley bottom in this village. However, these grazing lands deteriorated quickly and could not sustain all the animals that kept on increasing in numbers. The village council met and decided to restrict grazing lands to residents of this village. Farmers from the other two villages did not comply, and this has always resulted in violent clashes and endless disputes. Efforts to resolve this conflict have involved community leaders, local council (LC1) members of the three villages, and even the subcounty authorities, but these clashes continue every dry season, and people have lost animals and property.

There has also been escalation of different types of supra-community conflicts. These are grouped into four main types:

- Conflicts over protected areas and parks that oppose local community concerns for livelihoods and national and international concerns for environment and biodiversity conservation. Most of these conflicts were confined to areas around the Bwindi 
Table 2. Percentage distributions of farmers by number of natural resources management conflicts reported $(\%)$.

\begin{tabular}{llll}
\hline \hline Number of conflicts reported & Men & Women & Total \\
\hline No conflict reported & 01.4 & 01.4 & 01.4 \\
1-3 conflicts & 43.5 & 42.5 & 43.0 \\
4-6 conflicts & 31.9 & 31.5 & 31.7 \\
7-10 conflicts & 20.3 & 19.2 & 19.7 \\
More than 10 conflicts & 02.9 & 05.5 & 04.2
\end{tabular}

Impenetrable National Park, and opposed park authorities to communities living around the park. These were of two particular forms: crops that destroy wildlife and property, and people's encroachment on park resources. Crop raiding by wildlife was reported as a major form of conflict contributing to the hostility between local communities and the park authority. These animals, especially baboons and bush pigs, usually leave the park and destroy crops planted by farmers surrounding the park. These types of conflicts affect over $70 \%$ of farm households with farmland bordering the park in Ikumba, causing considerable crop losses.

- Encroachment on wetlands, forests, and protected areas. Although government agencies involving international actors restrict the use of such resources, e.g., wetlands, woodlots, forests, and associated resources, local communities consider them as common-pool resources with many opportunities for their livelihoods.

- Conflicts between different government policies and agencies over authority to regulate natural resource management, e.g., district agricultural office, environment, forest, and health departments. These conflicts are often caused by uncoordinated sectoral policies and regulations.
- Conflicts among local communities and elites, e.g., government authorities, NGOs, rich farmers, over grabbing and eviction from lands, privatization and expropriation of CPRs, trespassing on private property.

The most common type of conflict opposed local communities to the Bwindi Impenetrable National Park (BINP) in Ikumba subcounty. Previously designed as a forest reserve with relatively liberal and rarely reinforced regulations regarding access rights, Bwindi was accorded high protection status in 1991 as a national park and designated a World heritage site since 1994, and was renamed Bwindi Impenetrable National Park. This had immediate effect of closing all access to the forest products by adjacent communities, resulting in huge amounts of conflicts and resentment (Bloomley 2003). The park is surrounded by sloping terrain supporting one of the highest population densities in Uganda.

\section{THE DYNAMICS OF CONFLICT MANAGEMENT AND THE ROLE OF SOCIAL CAPITAL}

Over the last decade, the concept of social capital has risen dramatically to become one of the most fertile concepts in social science literature (Bourdieu 1983, Portes 1985,1998, Colleman 1988, Putman 1993, Uphoff and Mijayaratna 2000, Woolcock and Narayan 2000, Durlauf 2002, 
Gillinson 2004). Some of pioneering scholars of social capital such as Bourdieu (1983, 1985), Colleman (1988) and Putman (1993) considered social capital as a resource for action, which is developed and accessed through membership in formal organizations, Putman defined social capital as the features of social organizations such as social networks, social interactions, norms, social trust, and reciprocity, cooperation that facilitate coordination and cooperation and that enable people to act collectively for mutual benefits (Woolcock and Narayan 2000).

More recent formulations and studies using the concept of social capital build on these principles. Uphoff and Mijayaratna (2000) distinguish between structural and cognitive forms of social capital, refining the notions of shared norms and trust at individual and household levels, and the horizontal and vertical social networks constituting social capital. They define structural social capital as referring to the networks, linkages and practices within and between communities, including membership in formal and informal associations, participation in decision making and the forms of social organzation within which networks of relationships are located. In contrast, cognitive social capital refers to the attitudes, values, beliefs, social norms, and behaviors that exist within a community (Uphoff and Mijayaratna 2000, Grant 2001).

The two dimensions relate to a further refinement of the concept of social capital into "bonding," "bridging," and "linking" social capital (Pretty 2003). Pretty describes bonding social capital as the social cohesion within groups or communities resulting from relationships between people of similar ethnicity, social status and location, based on local ties, trust and shared moral values, reinforced by working together. Bridging social capital refers to the structural relationships and networks which cross social groupings, involving coordination or collaboration with other groups, external associations, mechanisms of social support or information sharing across communities and groups (Narayan and Pritchett 1999). Linking social capital crosses describes the ability of groups to engage with external agencies, either to draw on useful resources or to influence policies (Pretty 2003). Linking social capital crosses status, linking poor people and those in positions of influence.
The different aspects and dimensions of social capital determine whether a community can act as a cohesive unit, i.e., bonding, whether people comply with the norms and bylaws, i.e., structural; whether they have links with other community organizations, i.e., bridging, or whether they can access and influence institutions with more power and resources, i.e., linking, for managing natural resources, including conflicts. Results of this study show that farmers use several social capital mechanisms for managing conflicts. Although the specific mechanisms for managing conflicts vary with the conflict type, nature, levels, and stakeholders or actors involved, we found that people generally rely on five general mechanisms to manage conflicts: avoidance, negotiation, and mediation, arbitration, adjudication, and coercion. In many situations however, there is a combination of different resolution mechanisms, some time in synergy or sequence, but sometimes in contradiction and conflicts. These mechanisms correspond to and are activated by different types of social capital.

One of the traditional institutions for managing conflicts is the clan. Traditionally, the basic social organization of the Bakiga people of Kabale uses the agnatic lineage structure based on principle of patrilineal descent, which forms the core of social structures and permeates practically every aspect of life. There are several clans in each village, although two or three may be dominant. For example, in Karambo village, there are two dominant clans: Abagyeri and Abarihira, and four minor clans, Abaheesi, Abanyangabo, Abasigi and Abakongoro. In Kagyera, clans in order of size are the Abayondo, Abagunga, Abakongwe, Abaheesi, and Abasigi. Relationships between clansmen cut across neighborhoods. We found that $34 \%$ of conflict cases between farmers are handled by clan elders and community members who facilitated negotiation between conflicting parties to reach a mutually agreed decision. From the interviews, it was often reported that:

... There have not been serious (violent) conflicts in the village in the last $15 \mathrm{yr}$. Simple cases of disagreement with neighbors are solved locally by the elders. Misunderstandings between two people are taken to clan leaders who call four to six people as witnesses, to mediate the case and reach a decision. Usually what is decided is 
respected. If not, the cases are referred to the local councils (LCs) for arbitration.

Avoidance was often used when the conflict is trivial or of passing importance. The desire to avoid confrontation outweighs the need to bring conflicts into public domain. Interviews with a male farmer better capture such cases:

This woman... has been planting her sorghum in my farm without my permission for two seasons. The first time I allowed her to harvest her sorghum. The following season she went back and planted beans and now she is planting sorghum again. I have asked her to find another place to farm but she has refused. She is a widow and has no one to help her. If I take the case to the LC1, they will decide against her. I am just being patient hoping the woman may reform but she is not reforming. Maybe I will now take the case to the LC1 if she continues for six months. But I will see...

However, in a considerable number of cases (30\%), bonding social capital mechanisms, e.g., clan leaders, neighbors, relatives, village members, are perceived as having lower capacity for resolving conflicts, as most cases taken to them are often unresolved and often require intervention of other institutions for arbitration (Table 2). The main factor of this distrust is lack of power to improve sanctions. There is nothing clan elders and relatives can do to ensure that those who break the rules are punished. A combination of social, economic, and political factors has undermined the ability of local mechanisms, clan elders and community organizations to manage conflicts (Means et al. 2002). Also the more educated and wealthier farmers are not willing to accept decisions by local communities and clan elders and prefer to take their cases to government institutions at higher levels for arbitration rather than mediation and negotiation within the village. Other problems included biases, corruption and laxity of clan leaders. Although there are no financial costs associated with local mechanisms for resolving conflicts, a considerable number of farmers perceived local mechanisms as being biased. This perception was particularly significant for women compared to men, corroborating women's perceptions that local mechanisms are biased against them. Indeed most conflict cases involving women, or opposing women to their husbands' relatives are seldom resolved in women's favor, as illustrated by this woman's case:

When my husband died, my brothers-inlaw wanted to take our land and cows because I had five daughters and only one small boy. I pleaded with them that I needed the property to raise the children. They were only interested in the land, but not the welfare of their bothers' children. I appealed to the clan elders, but they were in favor of their relatives (my brothers-inlaw). My own relatives, neighbors and friends also tried to mediate, but the clan elders still decided to give the land to my brothers-in-law. Then I had no choice but take the case to the village local council (LC1). The LC1 leaders knew the background of the case as many of them were already involved in mediation and reconciliation attempts. They ruled in my favor, allowing me to continue using the land until my son becomes an adult to decide. But they also decided that I couldn't dispose of this land, or rent it, or exchange it with a more fertile land near the house. My brothers-in-law are not happy and they don't talk to or visit us.

In some other cases, conflicts between clan members or with other farmers emerged and become increasingly public, developing gradually and or rapidly because of a few significant events. In such cases, the capacities of clan leaders to resolve conflict become inappropriate, and conflicting parties take their cases to other social structures within the community. We also found that farmers' groups, and particularly women's groups have relatively high capacity to resolve conflicts and most cases are resolved through mediation and negotiation. Farmers' groups usually have high levels of structural social capital, e.g., trust and cooperation, norms and rules within groups, as well as bridging social capital, i.e., capacity of groups making links with other groups, and linking with the LC system. Since a considerable proportion of farmers belong to several groups, such groups have the advantage of facilitating mediation and negotiation, a voluntary process in which conflict parties meet to reach mutually acceptable decisions, and seek to seek to create a win-win outcome. However, this is most effective when conflicts 
Table 2. Percentage distributions of farmers by number of natural resources management conflicts reported (\%).

\begin{tabular}{llcc}
\hline \hline Number of conflicts reported & Men & Women & Total \\
\hline No conflict reported & 01.4 & 01.4 & 01.4 \\
1-3 conflicts & 43.5 & 42.5 & 43.0 \\
4-6 conflicts & 31.9 & 31.5 & 31.7 \\
7-10 conflicts & 20.3 & 19.2 & 19.7 \\
More than 10 conflicts & 02.9 & 05.5 & 04.2
\end{tabular}

oppose people belonging to the same group. For example, in Habugarama village, i.e., about 55 households, we identified about 10 local groups and organizations ranging from labor parties, credit and savings groups, pig rearing, farming groups, swamp association, to "Determined women," a drumming and singing group, mothers' unions, church-based groups, etc. This high density of local organizations suggests a relatively high level of social capital with a stronger capacity for managing conflicts.

However, although some communities have long been known to manage their natural resources conflicts effectively, recent years have seen the emergence of strict regulations or policies for sustainable management of natural resources. The decentralization process has established the local councils at village levels who concentrate both political and administrative powers to manage community life, including arbitrating disputes, making byelaws and enforcing government policies. A considerable number of farmers believed that a strong enforcement mechanism is the only way to prevent and resolve conflicts: "ABakiga nibategyekwa kifuba" The Bakiga people are stubborn. Many conflicts were resolved through arbitration, taking the case to lower levels of local government, LC1, who facilitate negotiation between parties and renders a decision. The LC1 has power to impose decisions and sanctions on the people (Table 3).
Results show that many of the NRM bylaws were perceived as being effective in preventing and resolving conflicts. About $40 \%$ of conflict cases were resolved through arbitration by local government village council members who are empowered by the Local Government Act to resolve disputes and conflicts. There are also some cases of conflicts, which were resolved through adjudication. We inventoried about 79 land related conflicts involving a variety of stakeholders. These involved conflicting and overlapping claims over land, including inheritance rights, land grabbing, and criminal trespass. The main outcomes of adjudication have been imposing fines $(67.8 \%)$ to the offenders, and imprisonment of offenders, i.e., 10 cases. Results concur with the observations of Means et al. (2002) that the court mechanisms are intimidating and inaccessible to the majority of farmers, especially women and the poor, who are often uneducated and live far from the magistrate courts at the subcounty and district headquarters. The judicial language and administrative procedures used in these courts are also alien to farmers. The time to resolve conflicts, administrative procedures, and other socioeconomic and political barriers also prevent farmers from resolving their conflicts using this channel (Table 4). 
Table 3. Relative importance of conflict resolution mechanisms.

Resolution mechanisms

Avoidance:

People don't report problems, they try to solve them

Mediation and Negotiation:

People usually rely on clan elders, relatives, neighbors and groups to solve conflicts

Arbitration:

People report problems to local government leaders (village council)

Adjudication:

People take problems to courts or are coerced to comply
Percent of responses

$(\mathrm{N}=667)$

34.8

29.3

39.9

2.5

\section{THE LIMITS OF SOCIAL CAPITAL}

One important finding from this study is that social capital mechanisms were not effective for managing conflicts between local communities and external powerful stakeholders. There are some disadvantages and limitations of different conflict management mechanisms (Table 5) In most conflict cases opposing local communities to park authorities and to government structures, the use of force and coercion including harassment, physical assault, intimidation, fines and imprisonment, was most common. Several cases and narratives confirm that the park authorities impose heavy fines for any encroachment on the park resources.

On the other hand, although farmers have reported such conflicts to local councils (LCs), they are often left unresolved. In many cases the park authorities used coercion as a mechanism to resolve conflicts, imposing their will through the use of force, exerting unequal power relation. The conflict is exacerbated by the lack of clear mechanisms of compensation and conflict resolution. There are unclear provisions in the Wildlife Statue and Local Government Act and uncertainties over who should deal with such conflicts as well as reluctance from Park authorities to consider the option of culling the animals. As a result of their frustrations and anger, farmers have also resorted to some forms of violence like setting fires to the park. Interviews with key informants confirmed Bloomley's report that about sixteen fires were started in and around the park by local residents with deliberate intent of destroying the park (Bloomley, 2003). The closure of the park to surrounding communities immediately resulted in violent escalation of conflicts between local communities and park staff.

In such supra-community conflict situations, the extent of linking social capital, that is the vertical relations between organizations, institutions, and communities and links with external and formal organizations, should become important in resolving conflicts. Kabale is arguably one of the districts where there is a high concentration of research and development organizations working on various dimensions of common-pool resources (CPR) and natural resource management (NRM) issues. For example, villages in Ikumba appeared to be well covered by external organizations (94\%) followed by Rubaya ( $81 \%$ ) and Bubare $(57 \%)$. The high concentration of development organizations in Kabale is mainly related to increasing concerns of environment conservation and protection of natural parks and forest reserves. Some of the international organizations have been facilitating community conservation initiatives, including conflict management. Bloomley (2003) provides an account of CAREDevelopment Through Conservation (DTC) project attempts to manage park conflicts through mediation and negotiation between local development interests of resource poor households and the 
Table 4. Capacity of actors and stakeholders to resolve conflicts.

\begin{tabular}{|c|c|c|c|c|}
\hline \multirow[b]{2}{*}{ Actors and Stakeholders } & \multicolumn{4}{|c|}{ Capacity of actors and stakeholders to manage conflicts } \\
\hline & Low $*$ & Medium** & $\operatorname{High}^{* * *}$ & $\begin{array}{l}\text { Not involved, can't } \\
\text { tell }\end{array}$ \\
\hline Clan elders & 31.1 & 12.4 & 56.6 & - \\
\hline Neighbours & 29.9 & 15.3 & 51.8 & - \\
\hline Relatives & 26.1 & 12.3 & 61.0 & - \\
\hline Church leaders & 8.6 & 10.7 & 75.8 & 5.0 \\
\hline Farmer groups & 13.3 & 8.4 & 64.1 & 4.2 \\
\hline Women groups & 17.0 & 7.0 & 70.4 & 5.6 \\
\hline Village Local Council (LC1) & 8.2 & 13.7 & 78.1 & - \\
\hline $\begin{array}{l}\text { Local Council II (LC2 } \\
\text { parish) }\end{array}$ & 22.6 & 30.2 & 43.8 & 3.5 \\
\hline $\begin{array}{l}\text { Local Council III (Sub } \\
\text { county courts) }\end{array}$ & 13.9 & 15.3 & 61.1 & 9.5 \\
\hline District court & 7.2 & 7.9 & 61.2 & 23.7 \\
\hline
\end{tabular}

*Low, conflict cases taken to them are often unresolved **Medium, some conflict cases are resolved but not always

***High, most cases are resolved

national and international interests of environment and biodiversity conservation. Although there have been some cases of successful arbitration and negotiation, the unequal power relation between the local communities and national and international stakeholders has often meant that conflicts are resolved through coercion. He found that there is an inequitable sharing of conservation costs and benefits between different stakeholders. Conservation costs are borne by marginalized poor households adjacent to the park, whereas the benefits are enjoyed by wealthier tourists in the global community and national and international level stakeholders. Also, a revenue sharing scheme between the park and local communities remains an issue of conflicts, in particular contested by local government. Revenue sharing scheme between the park and local communities remains an issue of conflict, in particular contested by local government.

We also found that in many cases, the adjudication process combined different mechanisms of conflict resolution in a complex fashion, and involved different actors at different levels. Some conflicts taken to the higher levels are referred back to the LC1 for more effective resolution mechanisms. In a significant number of cases, we found a positive synergy between social capital and local policy institutions or administrative procedures for resolving conflicts, as illustrated by James' case, a male farmer in Rubaya:

James had a problem with his brother who was trying to use force to grab land from him on the basis that he was the eldest son 
Table 5. Strengths and limitations of different conflict management mechanisms.

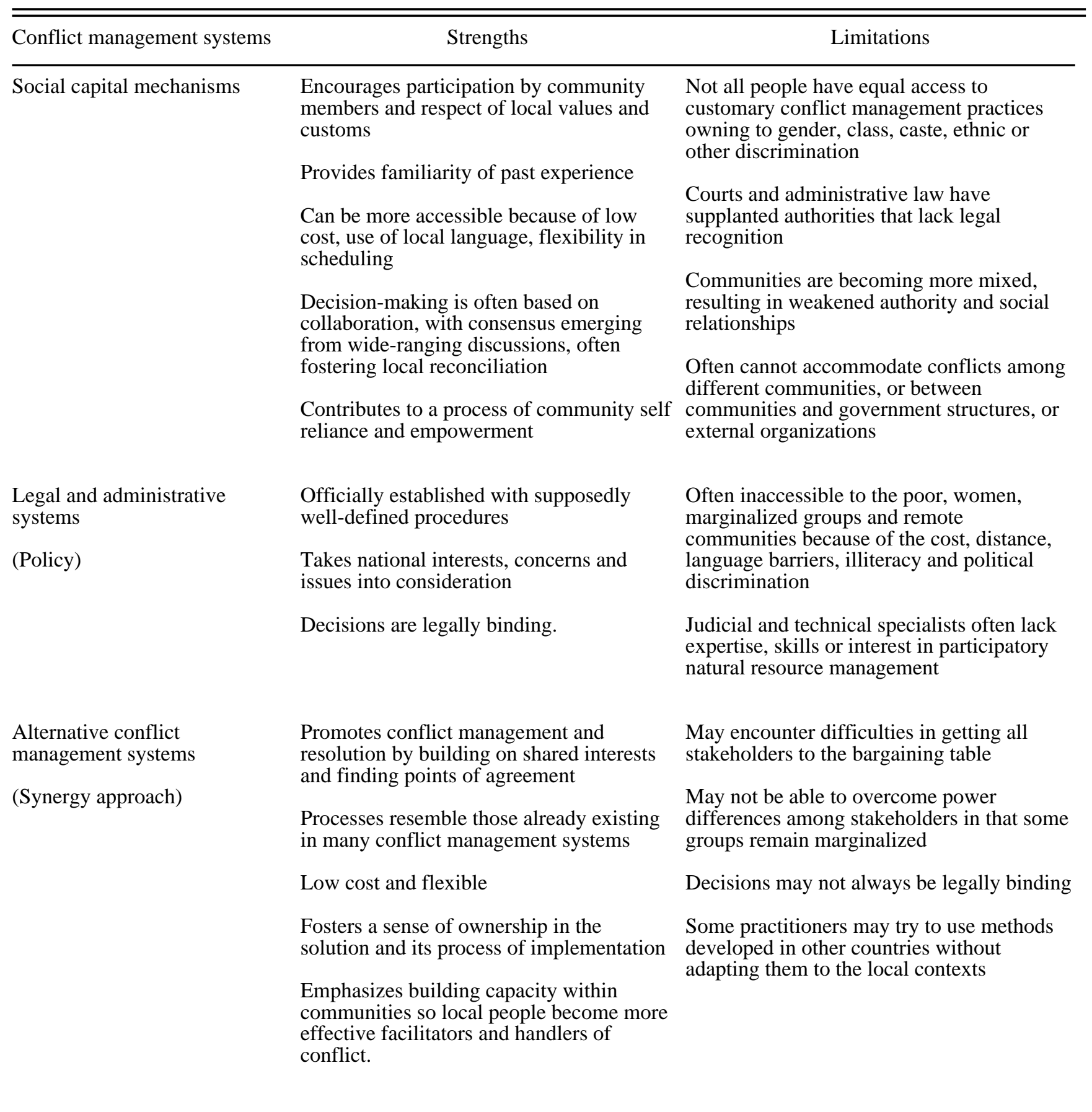

Source: Adapted from Means et al (2003) 
and had worked on the land with their father. They went to the elders who found the brother guilty, but the brother did not accept the verdict and decided to go to the Grade two magistrates. The magistrate referred the case back to the LC1 and village leaders. The LC1 and village leaders still ruled in favor of James. The brother was not satisfied and decided to take the case to the district court in Kabale where he could use money to win the case. He then sold that land. Subsequently he suffered some misfortunes and suspected his brother had bewitched him. He finally came back to the clan elders and village leaders to ask for reconciliation with James. He was fined and forced to give another piece of land to James...

\section{CONCLUSION}

The results of the study showed that a range of conflict minimizing strategies flow from different types and combinations of social capital and local polices. There is evidence that farmers and communities use a plurality of strategies, processes and avenues to resolve conflicts, and create checks and balances that a single conflict management system cannot generate. Social capital mechanisms have certainly a number of strengths and have been effective in a number of cases. For example, bridging and structural social capital as expressed in the density of farmers' groups, and particularly women's groups, have a relatively higher capacity to resolve conflicts as most cases are resolved through mediation and negotiation within these groups.

The study also shows that social capital mechanisms have some limits, and were not always effective in resolving certain types of conflicts. This is not surprising with respect to bonding social capital, given the characteristics of this capital. In fact, bonding social capital can be coercive and often leads to homophily (Newman and Dale 2005). Thus, there is a need for bridging and linking social capital as well as policy interventions. Many conflicts were resolved through arbitration and adjudication at different levels of local government. The village local council (LC1), which is the lower level of decentralization, was perceived as the most effective in resolving conflicts. Conflicts taken to the $\mathrm{LC} 1$ are usually resolved through arbitration and mediation, involving other community leaders. However, this confidence decreased significantly as one moves higher up the ladder to the LC 2 and LC3, which are more remote and distant to community social relations. At these levels, adjudication and coercion are generally used, and many farmers perceived the process as being biased and not equitable. There is substitution and exclusion of social capital mechanisms by policy structures. Many of these formal conflict resolution mechanisms often have a high social cost for local communities, especially to women and other vulnerable groups, who end up taking the burden of paying fines and other forms of social exclusion and coercion. Often, low levels of linking social capital and dysfunctional policies led to rampant conflicts. In many cases, there was substitution and exclusion of social capital mechanisms by formal administrative and political structures.

Results show that policies or social capital alone do not possess the resources needed to promote broadbased and sustainable conflict resolution strategies. Rather, when local policies and social capital were combined in a positive sum way, as in the case of LC system, conflicts were likely to be minimized. We therefore suggest the "synergy approach" of social capital (Woolcock and Narayan, 2000) and local policy for managing conflicts. The synergy between local policies and social capital is based on complementarity and embededness. Complementarity refers to mutually supportive relations between public and private actors, local government, and local communities and is exemplified in the decentralization framework that links state institutions to local communities in Uganda. Embededness refers to the nature and extent of the ties connecting people and communities and public institutions. With recent decentralization efforts in Uganda, the village local council is embedded in social relations and hence may be under pressure by the community to perform and be responsive to them. The LC is also seen as complementary to traditional mechanisms for resolving conflicts. In the same vein, farmers groups and clan elders have been assisting the LC1 in arbitration and mediation of conflicts. However, this synergy may only work where there are high levels of social capital and well functioning government policies that are coherent and credible. Where there are high levels of social capital, communities have the ability to develop coping mechanisms to deal with conflicts. Conversely, as shown in the cases of supracommunity conflicts, where there are low levels of 
linking social capital and dysfunctional policies, conflicts tend to become of high intensity and violent. Exclusion, coercion and violence are the mechanisms used to manage such conflicts.

Better understanding of how synergy between social capital and local policy can be strengthened is crucial to promote alternative conflict management mechanisms. Formal policy and informal social capital mechanisms work best when, through redistributive, integrative and capacity building measures, they strengthen the capabilities of stakeholders to enter into voluntary negotiation and mutually beneficial collective action to resolve conflicts. The tasks of research should therefore be to determine how the positive manifestations of social capital, e.g., cooperation, trust, norms, and institutional efficiency, can enhance the formulation and implementation of bylaws and rectify dysfunctional policies, and how local policies can strengthen community mechanisms for conflict prevention and resolution. Promoting a positive synergy between social capital and policy requires participatory social learning processes and more integrative policy processes that strengthen and build social and human capital to transform NRM conflicts into opportunities for mutually beneficial collective action for sustainable livelihoods. As noted by Evans 1996 and Tendler 1997 (In Molyneux 2002), successfully participatory projects have frequently depended upon a creative synergy between state policy and civil society.

Responses to this article can be read online at: http://www.ecologyandsociety.org/voll2/iss 1/art6/responses/

\section{Acknowledgments:}

We are grateful to the hundreds of female and male farmers for their active participation in the study. We thank Faustin Maganga, Isaac Minde and Luis Navarro for their insightful comments. This paper is an output from project $R 7856$ funded by the Natural Resources Systems Programme of the UK Department for International Development for the benefits of developing countries. We acknowledge additional support from the International Development Research Centre (IDRC) through a grant to the East and Central Africa Programme for Agricultural Policy Analysis (ECAPAPA) of the Association for Strengthening Agricultural Research in East and Central Africa (ASARECA). We take responsibility of the views expressed in the paper.

\section{LITERATURE CITED}

African Centre for Technology Studies (ACTS). 1999. Policy research on ecological sources of conflicts in sub-Saharan Africa. Nairobi, Kenya.

Agrawal, A., and C. C. Gibson. 1999. Enchantment and disenchantment: the role of community in natural resource conservation. World Development 27(4):629-649.

Bloomley, T. 2003. Natural resources conflict management: the case of Bwindi Impenetrable and Mgahinga Gorilla National Parks, Southwestern Uganda. Pages 231-250 in P. A. Castro and E. Neilsen, editors. Natural resource conflict management case studies: an analysis of power, participation and protected areas. Food and Agriculture Organization of the United Nations, FAO-Rome, Italy.

Borrini-Feyerabend, G. 1996. Collaborative management of protected areas: tailoring the approach to the context: issues in social policy. International Union for the Conservation of Nature, Gland, Switzerland.

Bourdieu, P. 1985. The forms of capital. Pages 8-21 in J. G. Richardson, editor. Handbook of theory and research for sociology of education. Greenwood Press, City, Connecticut, USA.

Bourdieu, P. 1983. Economic capital, cultural capital, and social capital. Soziale-Welt Supplement 2:183-198.

Bowles, S., and H. Gintis. 2002. Social capital and community governance. Economic Journal 112:412-426.

Bridger, J. C., and A. E. Luloff. 2001. Building the sustainable community: is social capital the answer? Sociological Inquiry 71(4):458-472.

Buckles, D., and G. Rusnak. 1999. Conflict and collaboration in natural resources management. Pages 1-12 in D. Buckles, editor. Cultivating peace: conflict and collaboration in natural resources 
management. International Development Research Centre, Ottawa, Ontario, Canada.

Buckles, D. 1999. Cultivating peace: conflict and collaboration in natural resources management. International Development Research Centre, Ottawa, Ontario, Canada.

Burton J., and F. Dukes. 1990. Conflict: practices in management, settlement and resolution. St. Martin's, New York, New York, USA.

Castro, P. A., and E. Neilsen, editors. 2003. Natural resource conflict management case studies: an analysis of power, participation and protected areas. Food and Agriculture Organization of the United Nations, FAO-Rome, Italy.

Cousins, B. 1996. Conflict management for multiple resource users in pastoralist and agropastoralist contexts. IDS Bulletin 27(3):41-54.

Durlauf, S. N. 2002. On the empirics of social capital. The Economic Journal 112:459-479.

Gillinson, S. 2004. Why cooperate? A multidisciplinary study of collective action. Working Paper Number 234. Overseas Development Institute, London, UK.

Grant, E. 2001. Social capital and community strategies: neighborhood development in Guatemala City. Development and Change 32:975-997.

Grootaert, C. 2001. Does social capital help the poor? a synthesis of findings from local level institutions studies in Bolivia, Burkina Faso and Indonesia. Local Level Institutions Working Paper Number 10. The World Bank, Washington, D.C., USA.

Hart, N., and P. Castro, editors. 2000. Conflict and natural resource management. Community Forestry. Food and Agriculture Organization. Rome, Italy.

Hendrickson, D. 1997. Supporting local capacities for managing conflicts over natural resources in the Sahel. a review of issues with an annotated bibliography. International Institute for Environment and Development, London, UK.

Knox, A., R. Meinzen-Dick, and P. Hazell. 2002. Property rights, collective action and technologies for natural resource management: a conceptual framework. Pages 12-44 in R. Meinzen-Dick, A. Knox, F. Place, and B. Swallow, editors. Innovation in natural resource management: the role of property rights and collective action in developing countries. IFPRI. Washington, D.C., USA.

Means, K., C. Josayma, E. Neilsen and V. Viriyasakultorn. 2002. Community-based forest resource conflict management. A training package. Volumes 1-2. Food and Agriculture Organization of the United Nations, FAO-Rome, Italy.

Meinzen-Dick, R., A. Knox, F. Place, and B. Swallow. 2002. Innovation in natural resource management: the role of property rights and collective action in developing countries. IFPRI. Washington, D.C., USA.

Meinzen-Dick, R., and R. Pradhan. 2002. Legal pluralism and dynamic property rights. CAPRi Working Paper Number 22, IFPRI. Washington, D. C., USA.

Molyneux, M. 2002. Gender and the silences of social capital: lessons from Latin America. Development and Change 33(2):167-188.

Ostrom, E. 1990. Governing the commons: the evolution of institutions for collective action. Cambridge University Press, Cambridge, UK.

Ostrom E. 1998. The institutional analysis and development approach. Pages 68-90 in E. T. Loehman and D. M. Kilgour, editors. Designing institutions and environmental and resource management. Edward Elgar, Chelthenam, UK.

Place, F., J. Ssenteza, and K. Otsuka. 2001. Customary and private land management in Uganda. Pages 195-233 in K. Otsuka and F. Place, editors. Land tenure and natural resource management. IFPRI, Washington, D.C., USA.

Portes, A. 1998. Social capital: its origin and application in modern sociology. Annual Review of Sociology 24:1-24.

Pretty, J. 2003. Social capital and the collective management of resources. Science 32:1912-1914.

Ramirez, R. 1999. Stakeholder analysis and conflict management. Pages 101-128 in D. Buckles, editor. Cultivating peace, conflict and collaboration 
in natural resources management. International Development Research Centre, Ottawa, Ontario, Canada.

Rasmussen, L., and R. S. Meinzen-Dick. 1995. Local organisations for natural resources management: lessons from theoretical and empirical literature. IFPRI, Washington D.C., USA.

Raussen, T., F. Place, W. Bamwerinde, and F. Alacho. 2002. Report on a survey to identify suitable agricultural and natural resources-based technologies for intensification in Southwestern Uganda. a contribution to the strategic criteria for rural investment in productivity (SCRIP) policy framework of the USAID Uganda mission. International Food Policy Institute. Kampala, Uganda.

Russell, D., and C. Harshbarger. 2003. Groundwork for community-based conservation: strategies for social research. Altamira Press. Walnut Creek, California, USA.

Sanginga, P., R. Kamugisha, A. Martin, A. Kakuru, and A. Stroud. 2004. Facilitating participatory processes for policy change in natural resource management: lessons from the highlands of southwestern Uganda. Journal of Agricultural Sciences 9(1):958-970.

Scott, P. 1998. From conflict to collaboration: people and forests at Mount Elgon, Uganda. International Union for the conservation of Nature and Natural Resources. East Africa Regional Office, Nairobi, Kenya.

Tyler, S. 1999. Policy implications of natural resource conflict management. Pages 263-280 in D. Buckles, editor. Cultivating peace: conflict and collaboration in natural resources management. International Development Research Centre, Ottawa, Ontario, Canada.

Uphoff, N., and C. M. Mijayaratna. 2000. Demonstrated benefits of social capital: the productivity of farmers' organizations in Gal Oya, Srilanka. World Development 28(11)1875-1840.

Upreti, B. R. 1999. Managing local conflicts over water resources: a case study from Nepal. AgREN Network Paper Number 95a, Overseas Development Institute, London, UK.
Woolcock, M., and D. Narayan. 2000. Social capital: implications for development theory, research and policy. The World Bank Observer 15 (2):225-249. 